D. Peillon MD, ${ }^{*}$ J. Dubost MD, ${ }^{*}$ J. Bienvenu MD, $†$ P.Y. Carry MD, ${ }^{*}$ C. Roche MD,* P. Breton MD, M. Freidel MD, $\ddagger$ V. Banssillon MD*

\title{
Acute normovolaemic haemodilution does not reduce the inflamma- tory process induced by facial surgery
}

The place of preoperative acute normovolaemic haemodilution (haematocrit $=28 \%-32 \%$ ) in reducing postoperative inflammation was evaluated after facial surgery. Thirty-two patients scheduled for mandibular osteotomy were randomized to a nonhaemodiluted group or to a haemodiluted group. The degree of postoperative inflammation was evaluated: first by an $x$ ray technique (radiotelemetry) providing measurements of the tissue thickness (quantitation of facial oedema), and second by the measurement of four acute phase protein plasma concentrations during the first postoperative week. Throughout the study, no changes in facial oedema or in variation of acute phase proteins were detected after haemodilution. It is concluded that acute normovolaemic haemodilution has no effect on the intensity of facial oedema and the biological inflammation process afier facial surgery.

Le but de cette étude prospective est d'évaluer l'effet de l'hémodilution préopératoire (hématocrite $=28 \%$ à $32 \%$ ) sur la réaction inflammatoire après chirurgie faciale. Trente-deux patients devant bénéficier d'une ostéotomie mandibulaire ont été étudiés. Après randomisation, 16 ont été hémodilués et 16 autres non-hémodilués. L'ampleur de la réaction inflammatoire postopératoire a été évaluée à l'aide de deux techniques. D'une part, par téléradiométrie, technique radiographique qui permet la mesure de l'épaisseur des tissus mous et donc lévaluation de la réaction oedémateuse postopératoire. D'autre part, par le dosage plasmatique répété de différentes protéines de linflammation durant la première semaine postopératoire. Les

\section{Key words}

BLOOD: transfusion, haemodilution; COMPLICATIONS: inflammation; SURGERY: facial.

From the Department of Anaesthesia*, Laboratory of Biology†, and Service of Maxillofacial Surgery $\ddagger$, CH LyonSud, 69495 Pierre-Bénite, France.

Address correspondence to: Dr. D. Peillon, Dpt. AnesthésieRéanimation, CH Lyon-Sud, 69310 Pierre-Bénite, France. Accepted for publication 27th November, 1994. résultats obtenus nindiquent aucune différence significative entre les groupes de patients hémodilués et non-hémodilués. L'hémodilution préopératoire n'aggrave pas mais également ne permet pas de diminuer la réaction inflammatoire locale après chirurgie de la face.

During acute normovolaemic haemodilution (ANH), analytical, experimental and clinical studies have shown that oxygen carrying capacity first increases and reaches, at a haematocrit of approximately $30 \%$, values $10 \%$ higher than under normal conditions. More importantly, the distribution of local $\mathrm{PO}_{2}$ values are more homogenously distributed when blood fluidity is improved by haemodilution. ${ }^{1-5}$

Thus, ANH may improve nutritional blood flow in ischaemic tissue and be effective in the control and management of postoperative facial oedema following facial surgery. ${ }^{6,7}$ However, there are no randomized studies assessing the antiinflammatory effect of ANH after surgery. Furthermore, previous studies have relied on subjective clinical criteria to quantify the inflammation process. The aim of this study was to assess the influence of ANH on the degree of facial oedema and on the elevation of acute phase protein plasma concentrations after mandibular osteotomy.

\section{Methods}

After approval by the local Medical Ethics Committee of the University Hospital of Lyon-Sud and informed consent from each patient were obtained, 32 patients (21 male and 11 female) scheduled for mandibular osteotomy were studied. Patients between the ages of 15 and 50 yr scheduled for mandibular osteotomy for facial dysmorphia were eligible. The operation was performed by the same surgeon using the same procedure, through a vestibular incision and with an osteotomy to separate the medial from the lateral cortex. Rigid fixation was performed with screws. Patients suffering other pathology (traumatic, infectious, tumoural, etc.) or receiving other 
therapy (steroids, salicylates, non-steroidal anti-inflammatory drugs) were excluded.

The patients received premedication with midazolam $\left(0.15 \mathrm{mg} \cdot \mathrm{kg}^{-1} \mathrm{im}\right)$. A peripheral vein was canulated for infusion of crystalloids (Ringer's lactate: 4 $\left.\mathrm{ml} \cdot \mathrm{kg}^{-1} \cdot \mathrm{hr}^{-1}\right)$. Anaesthesia was induced with droperidol $\left(0.15 \mathrm{mg} \cdot \mathrm{kg}^{-1}\right)$, flunitrazepam $\left(0.03 \mathrm{mg} \cdot \mathrm{kg}^{-1}\right)$, phenoperidine $\left(0.025 \mathrm{mg} \cdot \mathrm{kg}^{-1}\right)$, and muscle relaxation was achieved with pancuronium $\left(0.1 \mathrm{mg} \cdot \mathrm{kg}^{-1}\right)$. After tracheal intubation, the lungs were ventilated mechanically and anaesthesia was maintained with $50 \% \mathrm{O}_{2}$ and $50 \% \mathrm{~N}_{2} \mathrm{O}$ supplemented with phenoperidine if necessary.

The patients were randomized to a non-haemodiluted group (group $\mathrm{NH}, n=16$ ), or to a haemodiluted group (group $\mathrm{H}, n=16$ ). In group $\mathrm{H}$, the $\mathrm{ANH}$ was performed after induction of anaesthesia, and when a stable haemodynamic state had been achieved. Blood was withdrawn from a large venous catheter to obtain a haematocrit of $30 \%$. The amount removed was estimated from the theoretical total blood volume (according to weight, height and sex) and to the ratio between the initial and required haematocrit. ${ }^{8}$ Simultaneously, blood was replaced by the same amount of $4 \%$ albumin through another large venous catheter. During anaesthesia, haematocrit was measured in the middle and at the end of the period when blood was withdrawn and every hour during surgery. For all patients, haematocrit was always maintained $>25 \%$. Surgical blood losses were compensated by blood transfusion when haematocrit was $<25 \%$ (homologous blood transfusion in group $\mathrm{H}$, heterologous in group NH). When haematocrit was $>25 \%$, blood losses were replaced with albumin.

In the two groups, systemic methylprednisolone was given to prevent airway obstruction: at the beginning of surgery (after haemodilution procedure in group $\mathrm{H}$ ), 1.5 $\mathrm{mg} \cdot \mathrm{kg}^{-1} \dot{v}$, and after surgery, $1.5 \mathrm{mg} \cdot \mathrm{kg}^{-1} i v$ daily for three days. Patients received $50 \mathrm{mg} \cdot \mathrm{kg}^{-1}$ ampicillin (or $50 \mathrm{mg} \cdot \mathrm{kg}^{-1}$ erythromycin if they were known to have allergy to betalactamines) daily for three days.

For each patient, different venous blood samples and radiological measurements were obtained. Mandibular radiotelemetry was performed $48 \mathrm{hr}$ after surgery and two months later, when no residual facial oedema remained. In these full face radiotelemetries, the distance between skin and gonion was measured on both sides to assess soft tissue thickness and the mean value was calculated. The difference of soft tissue thickness between the second day after surgery (D2) and two months later was used to assess facial oedema at D2. This measurement of facial oedema was performed by a surgeon who did not know which patients had received haemodilution.

Blood samples were obtained to measure haematocrit, acute phase protein and total protein concentrations in
TABLE I Patient characteristics and preoperative biochemical variables (mean (SEM))

\begin{tabular}{lll}
\hline & $\begin{array}{l}\text { Group NH } \\
\text { (no haemodilution) } \\
(n=16)\end{array}$ & $\begin{array}{l}\text { Group } H \\
\text { (haemodilution) } \\
(n=16)\end{array}$ \\
\hline Sex (M:F) & $9: 7$ & $12: 4$ \\
Age (yr) & $27(2.2)$ & $22.9(2)$ \\
Weight (kg) & $58.8(3.2)$ & $58.5(2.2)$ \\
Height (m) & $1.68(0.02)$ & $1.69(0.02)$ \\
Duration of operation (min) & $178(12)$ & $170(10)$ \\
Preoperative & & \\
- Haematocrit $(\%)$ & $42.2(0.9)$ & $41.3(1.1)$ \\
- Total protein $\left(\mathrm{g} \cdot \mathrm{L}^{-1}\right)$ & $63.1(3.7)$ & $65.1(3.9)$ \\
- CRP $\left(\mathrm{mg} \cdot \mathrm{L}^{-1}\right)$ & $6(0.97)$ & $5(0)$ \\
- Haptoglobin $\left(\mathrm{g} \cdot \mathrm{L}^{-1}\right)$ & $1.23(0.11)$ & $1.33(0.12)$ \\
- AAG $\left(\mathrm{g} \cdot \mathrm{L}^{-1}\right)$ & $0.65(0.06)$ & $0.66(0.04)$ \\
- Fibrinogen $\left(\mathrm{g} \cdot \mathrm{L}^{-1}\right)$ & $2.49(0.011)$ & $2.72(0.14)$ \\
\hline
\end{tabular}

plasma. Haematocrit was measured by the microhematocrit method (Haematokrit ${ }^{\circledR}$, Hettich). The acute phase proteins included $\mathrm{C}$-reactive protein (CRP), haptoglobin, alpha $_{1}$ acid glycoprotein (AAG) and fibrinogen. Immunoephelometry using BNA (Behringwerke, Marburg, Germany) for the quantitation of $\mathrm{CRP}(\mathrm{N}<10$ $\left.\mathrm{mg} \cdot \mathrm{L}^{-1}\right)$, haptoglobin $\left(0.6<\mathrm{N}<1.6 \mathrm{~g} \cdot \mathrm{L}^{-1}\right)$, and AAG $\left(0.55<\mathrm{N}<1 \mathrm{~g} \cdot \mathrm{L}^{-1}\right)$. Fibrinogen was determined according to the micromethod described by Von Clauss (1.8 $\left.<\mathrm{N}<4 \mathrm{~g} \cdot \mathrm{L}^{-1}\right)$. The technique of Biuret was employed for the quantitation of total protein concentration in plasma $\left(60<\mathrm{N}<80 \mathrm{~g} \cdot \mathrm{L}^{-1}\right)$. Haematocrit, acute phase protein and total protein concentrations were measured the day before surgery (D-1), and every morning of the first (D1), second (D2), third (D3), fourth (D4), and seventh day (D7) after surgery. Within patient comparisons were made. Data are presented as the percentage of preoperative values.

The results are reported as mean values (SEM). Nonparametric data were analyzed between the two groups by the Wilcoxon rank sign test $(P<0.05$ was considered statistically significant).

\section{Results}

There was no difference between the two groups with regard to sex, age, weight, height, duration of surgery and biological data before surgery (Table I).

In group $\mathrm{H}$, the volume of blood withdrawn was 828 $\pm 62 \mathrm{ml}$. Only one patient required an autologous blood transfusion because haematocrit was $<25 \% 72 \mathrm{hr}$ after surgery. In this group, no defect in wound healing was observed. In the NH group, no patient received homologous blood transfusion. Haematocrit was higher in this NH group during the postanaesthetic periods $(P<0.001)$ (Table II). All patients in both groups showed total pro- 
TABLE II Measures of haematocrit (\%; mean (SEM) during postoperative period. Significant difference between groups: ${ }^{*} P<0.001$.

\begin{tabular}{lll}
\hline Days & $\begin{array}{l}\text { Group NH } \\
(\text { no haemodilution }) \\
(n=16)\end{array}$ & $\begin{array}{l}\text { Group } H \\
\text { (haemodilution) } \\
(n=16)\end{array}$ \\
\hline D-1 & $42.2(3.6)$ & $41.3(4.6)$ \\
D1 & $38.8(3.6) *$ & $30.3(3.6)$ \\
D2 & $38.4(3.8) *$ & $31.2(3.5)$ \\
D3 & $37.2(3) *$ & $30.8(3.4)$ \\
D4 & $37.4(3.8) *$ & $31.1(3.7)$ \\
D7 & $38.3(4.6) *$ & $31.3(4.2)$ \\
\hline
\end{tabular}

TABLE III Changes in plasma concentration (in \% of variation from preoperative value) of total protein during postoperative period. Data expressed by mean (SEM). Significant difference between groups: $* \mathrm{P}<0.05$

\begin{tabular}{lll}
\hline & $\begin{array}{l}\text { Group NH } \\
\text { (no haemodilution) } \\
(n=16)\end{array}$ & $\begin{array}{l}\text { Group } H \\
\text { (haemodilution) } \\
(n=16)\end{array}$ \\
Days & $(n=10)$ \\
\hline D-1 & $0(0)$ & $0(0)$ \\
D1 & $+5(1.3)$ & $+3(1.8)$ \\
D2 & $+9(1.5)$ & $+8(2.4)$ \\
D3 & $+9(2.4)$ & $+8(2.2)$ \\
D4 & $+6(1.9)$ & $+7(2.4)$ \\
D7 & $+4(2.7)$ & $+1(3)$ \\
\hline
\end{tabular}

tein concentrations increased after surgery. There was no difference between the two groups during the study (Table III).

All preoperative acute inflammatory plasma protein values were within the normal range. After surgery, acute phase protein concentrations were increased. The CRP serum level increased to a peak at the first postoperative day. Haptoglobin, AAG and fibrinogen responded by a strong increase within $24 \mathrm{hr}$, which was maximal between the second and third day. No differences were observed between the groups in CRP, haptoglobin or AAG levels during the different periods. The only concentration difference was an increase of fibrinogen at D4 (smaller incremental change in group H) (Table IV).

In all patients, radiotelemetry showed that soft tissue thickness was higher $48 \mathrm{hr}$ after surgery (D2) than two months later. The decrease of soft tissue thickness between D2 and two months ranged from $5.5 \mathrm{~mm}$ to 32 $\mathrm{mm}$ in the NH group and from $10.5 \mathrm{~mm}$ to $30.5 \mathrm{~mm}$ in the $\mathrm{H}$ group. There was no difference in facial oedema (Table IV).

\section{Discussion}

After facial surgery, different authors have observed a considerable inflammatory reaction with facial oedema. The ANH technique might reduce this process. In this
TABLE IV Changes in plasma concentration (in \% of variation from preoperative value) of acute phase proteins during postoperative period and measurement of soft tissue facial swelling at 48 hours after surgery. Data expressed by mean (SEM). Significant difference between groups: ${ }^{*} \mathrm{P}<0.05$.

\begin{tabular}{|c|c|c|}
\hline Days & $\begin{array}{l}\text { Group } N H \\
\text { (no haemodilution) } \\
(n=16)\end{array}$ & $\begin{array}{l}\text { Group } H \\
\text { (haemodilution) } \\
(n=16)\end{array}$ \\
\hline$C R P(\%)$ & & \\
\hline D-1 & $0(0)$ & $0(0)$ \\
\hline DI & $+1078(176)$ & $+889(115)$ \\
\hline D2 & $+918(149)$ & $+678(79)$ \\
\hline D3 & $+305(57)$ & $+228(33)$ \\
\hline D4 & $+105(25)$ & $+55(15)$ \\
\hline D7 & $+57(34)$ & $+87(37)$ \\
\hline \multicolumn{3}{|l|}{ Haptoglobin (\%) } \\
\hline D-1 & $0(0)$ & $0(0)$ \\
\hline D1 & $+20(8)$ & $+44(28)$ \\
\hline D2 & $+136(13)$ & $+174(49)$ \\
\hline D3 & $+180(18)$ & $+217(57)$ \\
\hline D4 & $+177(18)$ & $+215(57)$ \\
\hline D7 & $+153(22)$ & $+214(65)$ \\
\hline \multicolumn{3}{|l|}{$A A G(\%)$} \\
\hline D-1 & $0(0)$ & $0(0)$ \\
\hline D1 & $+54(8)$ & $+46(6)$ \\
\hline D2 & $+107(14)$ & $+102(10)$ \\
\hline D3 & $+110(16)$ & $+106(12)$ \\
\hline D4 & $+96(16)$ & $+93(11)$ \\
\hline D7 & $+83(16)$ & $+86(17)$ \\
\hline \multicolumn{3}{|l|}{ Fibrinogen (\%) } \\
\hline D-1 & $0(0)$ & $0(0)$ \\
\hline D1 & $+50(8)$ & $+39(11)$ \\
\hline D2 & $+78(12)$ & $+56(13)$ \\
\hline D3 & $+68(11)$ & $+48(12)$ \\
\hline D4 & $+64(8) *$ & $+36(12)$ \\
\hline D7 & $+53(12)$ & $+24(7)$ \\
\hline Swelling at D2 (mm) & $16.7(1.2)$ & $17.7(1.5)$ \\
\hline
\end{tabular}

study, the postoperative inflammation reaction was evaluated by radiotelemetry and by measurement of acute phase protein concentrations. The results showed no difference in the extent of oedema or in acute phase reaction between haemodiluted and non-haemodiluted patients.

When cardiac performance is not compromised, the principal effect of ANH at haematocrit values of approximately $30 \%$ is to increase oxygen delivery. Although the arterial oxygen content is reduced, systemic oxygen transport is increased by the higher cardiac output. ${ }^{1,9}$ Haemodilution changes the spatial and temporal distribution of red cell flow within the microcirculation and improves local oxygen supply in tissue ischaemia associated with shock as well as in arterial occlusive disease. ${ }^{3,11}$ Thus, there is the potential for perioperative dilutional therapy to improve nutritional blood flow in ischaemic tissues. ${ }^{1-5,9}$ 
The influence of ANH on the postoperative inflammatory process is uncertain because previous studies have relied on subjective clinical criteria to quantify the process. ${ }^{6,7}$ The challenge is to find objective criteria to measure inflammation. ${ }^{10,11}$ Radiological and biological criteria have been proposed. A photographic technique has been found to be unwieldly. It requires specialized equipment, and contains several potential sources of error (variations in patient position ... ). Although no completely satisfactory technique for measurement of facial oedema has been reported, teleradiometry seems to be a reproductible and objective technique, and is easier to perform than computed tomographic examination. ${ }^{12}$ With this technique, there were no differences between the two groups in this study.

The increases of CRP and other acute phase proteins concentrations correlate well with the severity of the tissue damage and indicate the intensity of the inflammatory process. The acute phase proteins increase during the time of the inflammatory process and tissue necrosis induced by surgery. When the tissue damaging process ceases, the serum concentrations of these proteins decrease towards normal. ${ }^{13,18}$ Among the acute phase reactants, CRP deserves special attention because its response is recognizable already within eight hours of the beginning of the inflammation, and reaches a maximal value 24 to $48 \mathrm{hr}$ later (>1000 time the normal concentration). ${ }^{13}$ This protein is one of the most specific indicators of the acute phase reaction after surgical trauma. ${ }^{13,15}$ Haptoglobin, AAG and fibrinogen react with differences in the delay and amplitude of the response. The increase is apparent with $24 \mathrm{hr}$ and is maximal after three days. The relative increase in concentration is lower for haptoglobin, AAG, and fibrinogen than for CRP (and higher for haptoglobin than for AAG and fibrinogen). ${ }^{15,17,18}$ In these conditions, these four proteins may be useful as a guide to assess therapy in studies and in clinical practice. In this investigation, serial quantitative acute phase proteins measurements were used to assess the extent of the postoperative acute phase response. The biological results showed no difference between the two groups. Only the fibrinogen incremental change was smaller in group $\mathrm{H}$ at the fourth postoperative day for which there is no explanation.

To achieve ANH, the amount of blood removed may be replaced either by crystalloid or colloid solutions. Compared with $4 \%$ albumin, crystalloids are not as effective in maintaining normovolaemia during the $24 \mathrm{hr}$ after ANH. Artificial colloid solution is an alternative to albumin. Using artificial colloid infusions in one group (haemodiluted group) might have modified the intensity of the inflammatory process. Using $4 \%$ albumin resulted in no differences in the total protein concentrations be- tween the haemodiluted and the non-haemodiluted groups after ANH. This assesses the effect on the postoperative inflammation process of the decrease in haematocrit specifically.

It was found previously that steroids decrease postoperative facial oedema. ${ }^{19-20}$ In this study, all patients received methylprednisolone to reduce the postoperative inflammation process. Despite this, and in comparison with other studies, acute phase protein concentrations increase in the same range (kinetic and amplitude) after surgery. These elevations of CRP, haptoglobin, AAG and fibrinogen concentrations may be useful in assessing the intensity and persistence of the inflammatory process induced by facial surgery.

It is concluded that radiological and biological evaluation of the postoperative inflammation process did not show any difference between the haemodiluted and the non-haemodiluted groups after facial surgery. This suggests that ANH does not increase the postoperative inflammatory process, nor reduce the intensity of the oedema and acute phase reaction.

\section{Acknowledgement}

The authors acknowledge the assistance of Dr. Boissel who carried out statistical analysis.

\section{References}

1 Crystal GJ, Rooney MW, Salem MR. Regional hemodynamics and oxygen supply during isovolemic hemodilution alone and in combination with adenosine-induced controlled hypotension. Anesth Analg 1988; 67: 211-8.

2 Messmer $K$. Oxygénation tissulaire au cours de l'hémodilution normovolémique. Annales d'Anesthésie Française 1979; 9: 823-8.

3 Dabadie P, Erny P, Destribats B. Hémodilution et oxygénation tissulaire. Ann Fr Anesth Reanim 1986; 5: 204-10.

4 Intaglietta $M$. Microcirculatory effects of hemodilution: background and analysis. In: Tuma RF, White JV, Messmer K (Eds.). The Role of Hemodilution in Optimal Patient Care. München: Zuckschwerdt Verlag, 1989; 21-41.

5 Messmer $K$. Acute preoperative hemodilution: physiological basis and clinical application. In: Tuma RF, White JV, Messmer K (Eds.). The Role of Hemodilution in Optimal Patient Care. München: Zuckschwerdt Verlag, 1989; 54-73.

6 Bonnet MC, Julia JM, Mathieu-Daudé JC, du Cailar J. Intérêt de l'hémodilution en chirurgie maxillo-faciale sur l'oedème traumatique postopératoire et sur la vitalité des lambeaux. Ann Fr Anesth Reanim 1986; 5: 243-8.

7 Lefevre JC, Laxenaire MC. Stricker M, Drouet N, George $E$, Dopff $C$. Expérience clinique de 184 cas d'hémodilution normovolémique intentionnelle en chirurgie plastique de la face. Ann Chir Plast Esthet 1986; 31: 189-92. 
8 Manel J, Garric J, Lefêvre JC, Laxenaire MC. Règle à calcul du volume sanguin à prélever pour réaliser une hémodilution normovolémique intentionnelle. Ann $\mathrm{Fr}$ Anesth Réanim 1988; 7: 427-32.

9 Messmer K, Kreimeier U, Intaglietta M. Present state of intentional hemodilution. Eur Surg Res 1986; 18: 254-63.

10 Breytenbach HS. Objective measurement of postoperative swelling. International Journal of Oral Surgery 1978; 7: 386-92.

11 Bertolami CN, Cohen CH, Chrzanowski RR. Quantitation of experimental postsurgical edema. J Oral Maxillofac Surg 1982; 40: 473-6.

12 Muller $L$. Céphalométrie et Orthodontie. Paris: SNPMD Editeur, 1983; 9-15.

13 Kaplan MH. C-reactive protein: relation to disease and pathological significance. Ann N Y Acad Sci 1982; 389: 419-22.

14 Kushner 1 . The phenomenon of the acute phase response. Ann N Y Acad Sci 1982; 389: 39-48.

15 Fischer $C L$, Gill C, Forrester MG, Nakamura $R$. Quantitation of "acute-phase proteins" postoperatively. Am J Clin Pathol 1976; 66: 840-6.

16 Kushner I. C-Reactive protein and the acute-phase response. Hospital Practice 1990; 30: 13-28.

17 Aronsen $K-F$, Ekelund G, Kindmark $C-O$, Laurell $C-B$. Sequential changes of plasma proteins after surgical trauma. Scand J Clin Lab Invest Suppl 1972; 29: 127-36.

18 Calvin J, Neale G, Fotherby KJ, Price CP. The relative merits of acute phase proteins in the recognition of inflammatory conditions. Ann Clin Biochem 1988; 25: 60-6.

19 Schaberg SJ, Stuller CB, Edwards SM. Effect of methylprednisolone on swelling after orthognathic surgery. J Oral Maxillofac Surg 1984; 42: 356-61.

$20 \mathrm{Habal} \mathrm{MB}$. Prevention of postoperative facial edema with steroids after facial surgery. Aesthetic Plast Surg 1985; 9: 69-71. 